\title{
A ÓPERA NO PROJETO DE MODERNIZAĈ̣̃O DO BRASIL (RIO DE JANEIRO, 1889-1914)
}

\author{
The opera in Brazil's modernizing project \\ (Rio de Janeiro, 1889-1914)
}

\section{RESUMO}

A ópera ocupou importante espaço na vida cultural do Rio de Janeiro, recebendo, durante o período de implantação da República, especial atenção de cronistas e críticos que atuavam na imprensa. Esses intelectuais percebiam no gênero músico-teatral uma forma de promover a civilização e o aprimoramento do gosto artístico da população da cidade. Assim, a ópera figurou, para parte significativa desses escritores, como aspecto que deveria ser contemplado nos planos de modernização, integrando-se a um projeto de civilização e modernização, articulado a outras propostas discutidas naquele momento, inclusive a própria reforma urbana do Rio de Janeiro colocada em prática nos primeiros anos do século $X X$.

Palavras-chave: Ópera, modernização, Rio de Janeiro, modernização musical.

\begin{abstract}
The opera has occupied important space in the cultural life of Rio de Janeiro, receiving, during the period of implementation of the Republic, special attention of chroniclers and critics who were in the press. These intellectuals perceived in opera a form to promote civilization and the improvement of the city's artistic taste.

Thus, the opera figured, for a significant part of these writers, as an aspect that should be included in the modernization plans, integrating a project of civilization and modernization, linked to other proposals discussed at that time, including the urban reform of Rio de Janeiro, put into practice in the early years of the twentieth century.
\end{abstract}

Keywords: Opera, modernization, Rio de Janeiro, musical modernization. 


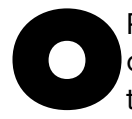

Rio de Janeiro, pelo menos desde a chegada da Corte portuguesa, em 1808, contava com espetáculos operísticos frequentes. $\mathrm{O}$ auge dessa atividade teria ocorrido no período do Segundo Império (FREIRE, 2013, p. 41) quando grandes artistas internacionais passaram pela cidade para temporadas de ópera. A Proclamação da República inauguraria um novo momento da história política brasileira, mas as mudanças trazidas pelo novo regime e todas as suas consequências pouco afetaram, em um primeiro momento, a afluência anual de companhias líricas e de outros gêneros músico-teatrais. Há registros de um expressivo número de espetáculos de ópera nos vários teatros da cidade, o que indica sua importância para a sociedade da época.

A historiografia brasileira sobre a Primeira República ou República Velha denominação repleta das ambiguidades típicas desse período - destaca o momento conturbado por que passara o país: crises econômicas, carestia, instabilidade política, revoltas, e uma reforma urbana que procurava esconder das vistas da alta sociedade e dos estrangeiros que aportavam na capital, os resquícios do que se considerava como atraso, ignorância, insalubridade. A Primeira República se estruturou, como bem afirma Lilia Moritz Schwarcz, sobre a ambiguidade e a contradição (SCHWARCZ, 2012, p. 27): uma modernidade de fachada, que visava resolver nas aparências os grandes problemas brasileiros que já se mostravam críticos na época.

Essa ambiguidade contrastava com o contexto do mundo ocidental, em que o otimismo tomava os espíritos nas grandes potências europeias. A belle époque deve seu nome à atmosfera de felicidade, paz e prosperidade que antecedeu à Primeira Guerra Mundial. No Brasil, diante das múltiplas crises e da realidade que teimavam em se sobrepor aos ventos do progresso, restou tentar colocar à força, compulsoriamente, o país nos trilhos da modernidade (SEVCENKO, 2003, p. 37). Superada a primeira década do novo regime, em que se acumularam mais frustrações do que realizações, o período de estabilidade e de revigoramento da economia deu lastro para obras que materializaram a belle époque brasileira, aprofundando ainda mais as contradições. Por um lado, vigorava a ideia de que um novo país demandava uma capital renovada e cosmopolita, que melhor se alinhasse aos ideais de progresso e civilidade, e que consistisse em vitrine do país. Com o presidente Rodrigues Alves (1902-1906), foi concretizado o audacioso plano de remodelação do Rio de Janeiro, em três frentes: a reforma urbana da capital federal, a cargo do prefeito Pereira Passos; a reforma do porto carioca, a cargo do político e engenheiro catarinense Lauro Müller; e o saneamento da cidade, sob coordenação do médico sanitarista Oswaldo Cruz.

O que se esperava da nova cidade era que esta se tornasse o espelho das pretensões das classes abastadas, tanto no que diz respeito à paisagem urbana, quanto ao modo de vida aburguesado. O modelo adotado foi a Paris do Barão de Haussmann, considerada então como o expoente do requinte e elegância, encarnação de todas as qualidades e virtudes da belle époque. A população pobre, que ocupava cortiços considerados focos de doenças, fora expulsa violentamente do centro da cidade e obrigada a abrir suas casas para os agentes de saúde pública. De fato, o auge da belle époque no Rio de Janeiro, se por um lado significou a concretização 
de um plano de modernização há muito aventado pela elite, por outro se deu de maneira autoritária, de cima para baixo, afetando a maioria da população, expulsa de suas moradias e tolhida de qualquer participação nas benesses da nova cidade.

A ópera se enquadrava perfeitamente nesse jogo de aparências e muito de sua sobrevivência como espetáculo preferido dos habitués dos teatros cariocas decorria de uma série de características atribuídas a ela. Afinal, a ópera era, por um lado, expressão cultural de uma elite letrada, que pretendia construir uma sociedade baseada em preceitos de civilidade europeus. Isso se reforçou no país ainda nos tempos do Império. Rogério Budazs destaca que "após a coroação de D. Pedro II a ópera passa cada vez mais a ser vista como propriedade cultural de uma elite que compreendia o idioma italiano e tinha familiaridade com as novas convenções do bel canto" (BUDAZS, 2010, p. 128). Era tomada como entretenimento aristocrático, cuja frequência tornava-se praticamente obrigatória a quem quisesse ser bem-visto perante a sociedade. Ademais, a ópera era um tipo de divertimento que valorizava o intelecto, ainda que aparente, além de ser muito apreciada na Europa. E o modelo de sociedade e cultura almejado era primordialmente o da França, não necessariamente o modelo real, mas sua representação no imaginário social reforçado constantemente pelos intelectuais que trabalhavam na imprensa.

Reconhecida como um entretenimento "chic", de bom gosto, ela possuía um papel de destaque na vida teatral e musical da cidade, papel este que seria ressaltado, sobretudo, no projeto de modernização da capital, Rio de Janeiro, com a inauguração do Theatro Municipal em 1909. Mais do que isso, era considerada, pelos intelectuais ligados à música, inclusive aqueles vinculados ao Instituto Nacional de Música, como um meio para se promover a civilização, aprimorando a sociedade brasileira, sua educação e gosto musicais (PEREIRA, 2015, p. 108). Nesse sentido, intelectuais discutiam em jornais e revistas em circulação no Rio de Janeiro sobre a necessidade de se melhorar o gosto musical brasileiro, ora criticando a assumida preferência do público pela ópera italiana, pela música vocal e pelos gêneros ditos "ligeiros" (a opereta, a ópera-cômica, o vaudeville, as mágicas etc.), ora considerando que a ópera bem apresentada, fosse ela italiana, francesa ou alemã, constituía-se como elemento fundamental para o crescimento e modernização da sociedade.

\section{A ópera como representação}

É importante destacar que, se afirmamos que a ópera era uma expressão cultural da elite, não quer isso dizer que ela estava restrita aos círculos da alta classe. Certamente, percebemos em alguma medida a ideia de que a ópera funcionava então como elemento de distinção de social. Jeffrey Needell reforça em alguma medida essa ideia ao destacar que a frequência à ópera estava intimamente ligada à percepção coletiva de que ela era um entretenimento de bom gosto, além possibilitar à alta classe carioca o desfile nos camarotes com as roupas da moda e a menção, no dia seguinte, nas colunas sociais dos jornais (NEEDELL, 1993). Mas não somente isso. Era premente, no intuito de civilizar o país, que hábitos culturais ditos civilizados fossem difundidos de maneira ampla na sociedade. Assim, eram múltiplos os significados atribuídos à ópera naquela época, assim como o papel que ela representava na 
sociedade também podia assumir diferentes formas.

Ao identificar e analisar os diferentes papéis desempenhados pela ópera na sociedade da belle époque no Rio de Janeiro, por meio dos discursos sobre o gênero artístico presentes nos jornais e revistas da época, percebemos que ela se situava na convergência de algumas relevantes disputas travadas na imprensa, que diziam respeito aos projetos que os vários grupos atuantes nos meios de comunicação elaboravam e idealizavam para o país. Os periódicos da época apresentavam, assim, características importantes para a compreensão da sociedade carioca da belle époque.

Analisar a ópera e suas representações elaboradas à época requer a apreensão de aspectos da sociedade daquele momento, suas disputas políticas, as dificuldades por que passava, as visões de mundo que se contrapunham. Entendemos, assim como Roger Chartier sugere para uma história cultural da leitura, que uma história da ópera nos primeiros anos da República brasileira deve ser compreendida no âmbito da construção de sentidos que a envolvem (CHARTIER, 2002, p. 27). Tomamos a ópera como representação de um ideal de sociedade, que também expressava suas contradições e contrastes. Compreendemos representação, nesse caso, como a presentificação de uma ausência; ou seja, a ópera, tomada como representação, apresenta-se à sociedade como presença de aspectos de uma sociedade ideal, europeizada, consonante a um ideal de civilidade então em pauta. Lembra o historiador francês que quando representação e representado são diferentes, existe "uma relação decifrável [...] postulada entre o signo visível e o referente significado - o que não quer dizer, é claro, que é necessariamente decifrado tal qual deveria ser" (CHARTIER, 1991, p. 184).

Dessa forma, a ópera funcionava como representação na medida em que ela era reconhecida como signo pela sociedade. Percebemos, dessa forma, um referencial simbólico que dava sentido às conotações associadas a ela, de maneira que a sociedade compartilhava valores nela incutidos. Esses valores são múltiplos e dependem, em grande medida, da posição social dos grupos que dela se apropriam, seus interesses, suas disputas por espaço. Há de se destacar, ainda, que o contexto que selecionamos para apreender os significados da ópera - que diz respeito à mudança de regime, do monárquico para o republicano - é pleno de representações e de disputas por aquilo que Bronislaw Baczko denominou de imaginário social, identificado pelo autor como um duplo fenômeno: por um lado, atuando na produção de representações da "ordem social" e, por outro, estabelecendo uma relação dialética entre a atividade imaginativa individual em um fenômeno coletivo (BACZKO, 1985, p. 308).

Os conceitos de representação e imaginário estão estreitamente vinculados, uma vez que, para que as representações revelem seus sentidos, elas dependem de uma estrutura compartilhada de pensamento e valores coletivos, que correspondem, segundo Baczko, ao imaginário social, consistindo, por sua vez, em uma das "forças reguladoras da vida colectiva" (Idem, p. 309). Representação e imaginário social são, dessa forma, conceitos-chave para a compreensão de nosso objeto de pesquisa, uma vez que estamos a trabalhar, também, com discursos dos críticos, em que se 
projetava uma série de representações.

Intentamos perceber nas fontes consultadas as inúmeras representações elaboradas sobre a ópera e sua relação com uma sociedade almejada pela elite. Nas palavras da historiadora Sandra Pesavento, buscamos "decifrar a realidade do passado por meio de suas representações, tentando chegar àquelas formas, discursivas e imagéticas, pelas quais os homens expressaram a si próprios e ao mundo" (PESAVENTO, 2003, p. 42). Levamos em consideração, tal como afirma Stuart Hall, que "em toda cultura há sempre uma grande diversidade de significados a respeito de qualquer tema e mais de uma maneira de representá-lo ou interpretáIo" (HALL, 2016, p. 20). As representações elaboradas sobre a ópera, sobretudo aquelas formuladas no período da belle époque, dialogavam com as noções de modernidade e ciência, então em voga. Foi necessário que dispuséssemos de um olhar cuidadoso, indo além do que as fontes se mostravam em sua superficialidade, considerando seus silêncios e lacunas, sua intencionalidade em ressaltar alguns aspectos em detrimento de outros. Assim nos aproximamos da complexidade de sentidos em que estava envolta a ópera, evitando abordá-la como restrita a um estrato social específico, da elite, pré-estabelecido.

Nesse sentido, a ópera é percebida como uma expressão cultural de valores específicos, certamente vinculados à elite, mas não restrita a ela. Seguindo os conselhos de Chartier, intentamos nos distanciar da percepção de que "as clivagens culturais estão forçosamente organizadas segundo um recorte social previamente construído" (CHARTIER, 1991, p. 180). Consistia, certamente, em representação de uma visão de mundo que deveria ser difundida, envolvendo, pois, os conflitos que lhe são inerentes e acentuados pelas disputas de poder que estavam então em jogo, na batalha por um modelo de sociedade que perpassava, também, pela música e pela ópera.

Tecer uma apreciação crítica sobre a ópera, nesse sentido, significa ainda extrapolar a tradicional dicotomia cultura erudita/cultura popular, maneira pela qual foram por muito tempo debatidos os temas relacionados à cultura (HALL, 2016, p. 19). Assim, problematizamos as interpenetrações e conflitos entre ambas, percebendoas, sobretudo, em sua relação dialética, explorando o conceito de circularidade cultural desenvolvido por Mikhail Bakhtin (BAKHTIN, 1999). Consideramos cultura um sistema de representações, compartilhado entre indivíduos que se relacionavam em coletividades historicamente situadas. Mas é preciso frisar que isso não significa que a cultura seja estanque, isolada ou restrita somente a um determinado grupo social. A esse respeito, nos parece útil a ideia de Bakhtin, que rompe com o preceito de que cada grupo desenvolve de maneira isolada o seu sistema de significações, seus valores, seus costumes, ao constatar que existe uma intercomunicação, ou uma circulação de ideias, valores e significados, estabelecendo assim relações com outros grupos, exercendo, enfim, influências mútuas, ou, nas palavras de Carlo Ginzburg, um "influxo recíproco entre cultura subalterna e cultura hegemônica” (GINZBURG, 1998, p. 21).

Dessa forma, tomando como ponto de partida a percepção da circulação cultural, aplicando-a ao nosso objeto, é impossível compreender a cultura como expressão 
pura e incomunicável de grupos específicos, assim como é equivocada a ideia de compreender a ópera sem considerar as influências a que estava sujeita. No caso em que nos debruçamos, percebemos essa interligação ou dialogismo nas iniciativas de tornar a ópera acessível ao "povo" e na busca por aspectos do folclore para a construção de uma música erudita nacional (ANDRADE, 2013, p. 21-22). Certamente, a própria produção musical e, notavelmente, a produção operística não conseguiria se isolar no interior do teatro, chegando de alguma maneira às ruas, tornando-se acessível a várias camadas da população. Mas não só isso. Não se tratava tão somente de um movimento acidental, como em certa medida, proposital. Nesse sentido, registramos as cobranças dos críticos e intelectuais em relação ao governo, para que se colocassem em prática políticas públicas voltadas para a difusão cultural, com vistas à predominância das vozes elitistas e à aniquilação, se possível fosse, dos aspectos relacionados à cultura popular, especialmente a urbana, impregnada por caracteres que afetavam, segundo os intelectuais da época, a própria moral da sociedade carioca.

Retomando o que nos ensina Bakhtin, é fundamental que um estudo sobre a cultura dita oficial, erudita, dominante - porque expressa valores de uma elite que se encontrava no comando da sociedade e precisava legitimar suas ações - leve em consideração a cultura popular, sob risco de deformar nossa interpretação acerca do passado. Adverte-nos o autor de que "cada época da história mundial teve o seu reflexo na cultura popular. Em todas as épocas do passado existiu a praça pública cheia duma multidão a rir" (BAKHTIN, 1999, p. 419).

Devemos ainda reforçar, como já dissemos, que as interpenetrações culturais geram conflitos, uma vez que está presente a disputa por espaço, por hegemonia. Se a ópera possuísse um lugar de prestígio assegurado na sociedade da belle époque carioca, não haveria necessidade de jornalistas, críticos e demais intelectuais escrever e discursar a seu respeito, no intuito de sensibilizar os leitores para que fossem aos teatros assistir aos espetáculos. Compreendemos, assim, que a ópera era símbolo de uma cultura dominante cuja hegemonia não estava assegurada, sendo constantes as ameaças, representadas por outras formas de arte e entretenimento, especialmente aquelas consideradas "popularescas", como a ópera-cômica, os vaudevilles, as mágicas, as operetas etc., que poderiam colocar a perder todo um ideal que se desejava implantar.

É importante ainda assinalar que a ópera poderia ser compreendida como uma prática estruturante das representações a ela associadas. Contudo, ao contrário de Chartier, que propõe perceber as práticas submetidas às matrizes das representações coletivas (CHARTIER, 1991, p. 183), ou seja, em níveis diferentes, preferimos a reflexão proposta nesse sentido por Raymond Williams, sobre a existência de uma relação dialética entre representações e práticas. Williams advoga pela convergência de ambas, com a finalidade de possibilitar uma visão sem hierarquias ou diferenças de nível entre elas (WILLIAMS, 2011, p. 13). Nesse sentido, consideramos a ópera como uma expressão cultural que consiste, simultaneamente, em representação e "prática significante". A prática não está simplesmente inscrita em redes ou sistemas de representações, mas elas auxiliam na construção dos sentidos, ora reforçando, ora 
criando significados. Dito de outra forma, ela não só espelha um conjunto de valores, mas é fundamental para a atribuição de significado e sentido. Ao considerarmos a ópera como obra de arte, observamos a mudança, enfim, de seu papel na sociedade: não como reflexo, mas como parte do discurso explicativo da sociedade que a cria, dando inteligibilidade e sentido a esses valores; em outras palavras, em vez de pensarmos que as práticas dependem da "matriz de representação" para fazer sentido, entendemos que há uma dependência mútua entre ambas.

Tais sentidos são coletivos, de forma que as representações elaboradas acerca da ópera estabelecem e definem afinidades e diferenças, constituindo-se em referência para a produção de identidades sociais. Sabemos que, em termos práticos, é impossível dissociar cultura de identidade. A identificação de um sujeito a um grupo se dá por meio do sistema de significações compartilhado socialmente, bem como as práticas que então auxiliam na construção e no reforço de tal sistema, conforme vimos acima. De acordo com Stuart Hall, ao trabalharmos com o conceito de representação, estamos trabalhando diretamente com a identidade (HALL, 2016, p. 25). Assim, devemos compreender o conceito de identidade também como "identidade cultural", pois por definição elas estão intimamente ligadas. Nesse sentido, percebemos que, ao tomarmos a ópera como representação ou como componente de um sistema simbólico, perpassamos inevitavelmente pelo conceito de identidade, uma vez que se faz necessário "pensar a questão do público como um agrupamento de agentes sociais que produz e consome a música, que interage com a obra de arte e que forma, de maneira mais ou menos análoga, certa identidade entre as pessoas que o compõe" (MONTEIRO, 2010, p. 88).

Há ainda que se considerar a importância legada pela historiografia sobre os primeiros anos da República à questão da formação da identidade nacional, que traz em seu bojo ideais de civilidade que repercutiriam, enfim, no gosto musical a ser desenvolvido naquele momento. José Murilo de Carvalho, adotando o conceito de Baczko acerca da imaginação - ou imaginário - social, nos mostra que a Proclamação da República demandou a construção de elementos que fundamentassem a nova identidade nacional, como forma de legitimação do novo regime ao mesmo tempo em que se buscava a reafirmação da unidade do país (Cf. CARVALHO, 1990). Tal processo se deu, conforme demonstra o historiador, na definição de novos símbolos - ou reaproveitamento dos velhos, revestidos de novos significados - que legassem a almejada unidade, o sentimento de pertencimento a uma nova nação, que então renascia como República. Destaca Carvalho que a "manipulação do imaginário social é particularmente importante em momentos de mudança política e social, em momentos de redefinição de identidades coletivas” (Idem, p. 11). Foi assim, portanto, que se deu a construção de toda uma simbologia e a escolha de marcos identitários que remetessem à nova ideia de nação republicana: a bandeira nacional, o hino, os heróis, as datas cívicas etc.

Algo semelhante pode se verificar em relação à ópera. Ao analisarmos os textos dos críticos que atuavam na imprensa, percebemos que está subjacente a eles um discurso acerca de um ideal de nação, que deveria ser colocado, divulgado e construído. Destaca Baczko, nesse sentido, que em momentos de mudanças, 
compete às elites a apropriação e a ressignificação de ritos e símbolos como forma de influência e manipulação, uma vez que esses rituais e símbolos "fornecem um cenário e um suporte para os poderes que sucessivamente se instalam, tentando estabilizar-se" (BACZKO, 1985, p. 324). Nesse ponto, a educação tem uma função importante, opondo-se à instrução, que simplesmente visa à difusão de saberes. A educação tem como intuito "formar almas" (Idem), mexendo com o imaginário coletivo, as representações que ele incute e provocando sentimentos em seus interlocutores. Nesse sentido, alguns intelectuais da belle époque acreditavam que a música, e incluída nessa categoria a ópera, possuía papel preponderante na formulação de uma nova nação, baseados em ideais positivistas, bastante correntes então.

Dessa forma, percebemos a ópera não apenas como um símbolo compartilhado somente entre aqueles que discutiam, formulavam e forjavam uma identidade nacional fundada em seus valores. Era também um marco da identidade social, parte de um conjunto de rituais que consolidavam o pertencimento a um determinado grupo. Como entretenimento de bom gosto, congregava ao seu redor um grupo que se pretendia distinto por seus hábitos elegantes, alinhados aos costumes sociais da burguesia europeia, sobretudo a francesa. A ópera, para este seleto grupo, era símbolo de status, de uma posição privilegiada em que a outra face seria a exclusão. Ela servia de demarcação de um espaço cujo acesso era restrito a um grupo. Perpassa, assim, as diferenciações sociais, de afirmação de uma classe que vê na ópera uma forma de se afirmar, de se mostrar, de ostentar, de se distinguir. Destarte, "[seguir] os modelos de comportamento significava inserir-se e fazer parte de um determinado grupo que se diferenciava dos outros pela postura, pelo gosto e pelo costume" (MONTEIRO, 2008, p. 67). Ao mesmo tempo em que a ópera representava um elemento de identificação, firmava-se como elemento de alteridade, por consistir em um fator de diferenciação e distinção a partir do gosto, de um grupo em relação a outro (Cf. BOURDIEU, 2007).

\section{A ópera e o projeto civilizador da Primeira República}

São poucos os estudos no âmbito da História Cultural que procuraram se debruçar sobre as manifestações culturais tradicionalmente ligadas à elite ou à cultura hegemônica, em geral consideradas conservadoras. De acordo com Chartier, isso se deve, pelo menos em parte, à zona de conforto do historiador, acostumado a se amparar em longas séries documentais e pela "preferência dada ao maior número, logo à investigação da cultura tida como popular” (CHARTIER, 2002, p. 15). Vemos uma grande profusão de teses e publicações que privilegiam a cultura popular, que no âmbito da música e do teatro da Primeira República, se manifestava, sobretudo, no samba, no choro, no teatro de revistas etc. No sentido oposto a essa tendência, partimos da ópera, entendendo suas relações com a cultura subalterna, a disputa por espaço e por público, no âmbito de projetos civilizadores que eram veiculados pela imprensa.

Naquele momento, talvez a ópera não consistisse num movimento típico avantgarde, de ruptura com preceitos artísticos e estéticos há muito estabelecidos. Sobretudo se considerarmos que o repertório operístico preferido pelo público 
frequentador dos espetáculos no Rio de Janeiro era repetitivo e baseado em títulos mais antigos, o que era alvo de críticas por uma parte da imprensa especializada. Ademais, a geração modernista que se seguiria a esse período iria desenvolver acentuada censura ao estrangeirismo que caracterizou o gosto artístico - e musical - de que foram eles próprios herdeiros. Contudo, ao analisarmos os discursos sobre esse gênero músico-teatral nas folhas dos periódicos da época, vemos sua adequação ao que se tinha então como moderno e avançado.

É importante ressaltar, antes de qualquer coisa, que os jornais e as revistas em circulação na época exerceram um importante papel, como testemunhos - registrando as discussões e impressões dos intelectuais que ali escreviam -, e como difusores de concepções e valores, procurando indicar os rumos que a recém-instituída República deveria seguir. Veiculava, pois, representações, na intenção de pautar o imaginário social. Os textos publicados pelos periódicos consistem, portanto, em fontes históricas, representações de um passado, uma vez submetidas a procedimentos metodológicos que visem não só compreender o que foi escrito, mas buscar os seus sentidos na relação do texto com seu autor e seu contexto. Essas fontes expressam em grande medida as impressões subjetivas dos autores, suas esperanças e desilusões; é o resultado de múltiplas escolhas - do cronista, do diretor do periódico, da sua linha ideológica e das expectativas dos leitores (DE LUCA, 2005, p. 133). Como fontes, estão repletas de lacunas, de não ditos, de esquecimentos, propositais ou não. No que tange à análise dos espetáculos operísticos, especificamente, essas fontes se imiscuem em aspectos pessoais de gosto, de concepção de arte, cultura e sociedade. Nos textos devem ser identificados, ainda, disputas por credibilidade, poder e influência, pessoais e empresariais - os jornais analisados já se inseriam em uma lógica mercadológica e empresarial (SODRÉ, 1999, p. 274-275). Constituem - ou visam constituir - dessa forma, uma memória coletiva, social, articulando lembrança e esquecimento, invocando diferentes temporalidades - passado, presente e futuro. Vale ressaltar que a memória é parte do sistema de representações que mencionamos anteriormente, vinculada ao imaginário social, tendo seu papel na elaboração de sentidos e na construção narrativa dos discursos de críticos e cronistas.

A presença da ópera nos jornais intensificava-se durante as temporadas líricas cariocas, quando além das notas acerca de novas óperas, cantores famosos, compositores, empresários, temporadas líricas em diversas cidades do Brasil e do mundo, eram acrescidas as críticas aos espetáculos, além dos anúncios e das chamadas para as récitas. A principal temporada teatral do Rio de Janeiro dava-se no inverno, ocorrendo nessa estação o ápice da atividade dos resenhistas, que promoviam verdadeiras batalhas em suas colunas: "Eis que volta a estação dos espectaculos, dos concertos e das festas. A critica está a postos, de espingarda engatilhada, pompta a fazer fogo, quer sobre os artistas, quer sobre si mesma, dividida que está em dous partidos adversos" (Artes e Manhas. Gazeta de Noticias, 26 maio 1897, p. 1). O movimento sazonal das companhias teatrais e líricas, bem como de sua crítica, foi assim descrito pelo periódico Don Quixote:

O marasmo dura de Dezembro a Maio - meio anno. - Na outra serie de mezes ha theatro. O que falta num semestre superabunda no outro. As 


\begin{abstract}
companhias estrangeiras vem como as andorinhas e os deputados e durante alguns mezes a secção teatral dos jornaes cresce, os theatros todos são occupados e o publico apparece mais ou menos.

A chronica acompanha a evolução - faz parte da estação teatral. Mingua quando não ha nada a dizer e avulta quando pululam as "primeiras" e os theatros todos funccionam.

$[\ldots]$

O assumpto não falta, avante chronista, multiplica-te para ver tudo, enche papel, muito papel para tratar de tudo.

(FOGUETE, E. Symphonia. “Theatros”. Don Quixote, 03/08/1901, p. 7)
\end{abstract}

O tema ocupava, sobretudo entre junho e outubro (por vezes se estendendo até novembro) de cada ano, um espaço considerável nos jornais e revistas. Registramos alguns casos particulares dignos de nota, como o destaque de primeira página da edição de 19 de março de 1893 do jornal O Paiz, dedicado à première europeia do Falstaff, última ópera de Verdi. As críticas das apresentações de ópera podiam tomar várias colunas, especialmente quando uma nova ópera, muito esperada, era enfim levada aos palcos cariocas. Nesses casos, era comum que os jornais trouxessem, antes da apresentação, informações detalhadas acerca da obra, para orientar o público sobre o enredo. Eram comuns ainda as homenagens a compositores, como o longo texto de Oscar Guanabarino em obituário de Giuseppe Verdi, publicado na primeira página de O Paiz de 24 de janeiro de 1901, ou os detalhes da estreia de uma nova versão do Fausto, de Gounod, na Opéra Garnier, em Paris, destaque do mesmo periódico em 25 de fevereiro de 1908, à página 4.

No que tange à crítica musical, o jornal O Paiz, periódico republicano existente desde 1884, contava com uma das figuras mais proeminentes e polêmicas de seu tempo, Oscar Guanabarino. Outros importantes periódicos da época também possuíam críticos influentes. A Gazeta de Notícias (criada em 1874) e o vespertino A Notícia (1894) - jornais que contavam com os mesmos elementos na redação (SODRÉ, 1999, p. 265) - dispunham de colunas periódicas assinadas por Luiz de Castro. No Jornal do Commercio ${ }^{1}$ atuava como crítico, desde os primeiros anos da década de 1890, José Rodrigues Barbosa, músico amador que, como Castro, estabeleceria estreitas ligações com o Instituto Nacional de Música, deflagrando várias polêmicas com Guanabarino (Cf. PEREIRA, 2007). Outros periódicos, como revistas semanais e ilustradas, também dedicavam algum espaço à ópera, tratando das apresentações de forma superficial. Os principais veículos de divulgação e crítica eram, de fato, os jornais diários, que corriam contra o tempo para dar, antes dos concorrentes, as notícias sobre o espetáculo. Ao crítico cabia escrever seu texto no exíguo "espaço de tempo que medeia o cahir do panno, no final da peça, e o concluir da paginação da folha, que deve ser impressa em poucos instantes", conforme relata Guanabarino, em crítica à ópera Africana, de Giacomo Meyerbeer, publicada no jornal O Paiz de 18 de junho de 1889. Tal urgência significava, por vezes, certo improviso ou mesmo o uso de artifícios para que o texto estivesse pronto a tempo. Por isso, não são incomuns acusações de plágio (FERREIRA, 2017, p. 34) e do uso de aspectos "ficcionais", tais como revela Lima Barreto (BARRETO, 2002). ${ }^{2}$

Na percepção de vários resenhistas, a crítica possuía uma função educadora 
clara, atribuindo à imprensa um papel fundamental no progresso das artes no país. O caráter pedagógico da crítica assumia uma dupla função, ao se ocupar tanto da construção do trabalho artístico, auxiliando artistas em seu processo criativo e técnico, quanto da preparação do público para receber uma obra. Esse aspecto é destacado por profissionais da crítica de arte até recentemente. Barbara Heliodora, em texto reflexivo acerca de seu métier, explora a contribuição da crítica artística na construção do próprio objeto analisado, seja ele a obra em si ou o artista intérprete. Para a autora o "crítico colabora com o processo criativo, nem sempre diretamente o criador, porém não há dúvida que ele o faz quando prepara um público potencial para apreciar um espetáculo" (HELIODORA; DEL RIOS; MAGALDI, 2014, p. 8-9). Em vários momentos, os críticos defendiam a necessidade de lapidação do gosto do público, procurando desenvolver nele o senso crítico, de forma que a audiência aprendesse a perceber - e discernir - o que era bom e o que era ruim. A exigência de alguma qualidade nas companhias líricas que se apresentavam na cidade, independente do público a que visavam, estava relacionada à necessidade em dar ao público bons parâmetros para julgamento, em conformidade a algumas normas estéticas e técnicas. Pretendia-se, dessa forma, que com o tempo, gêneros considerados menores e popularescos fossem abandonados em benefício da arte "de alto nível”, classificação em que se incluíam a ópera e os concertos sinfônicos.

A forma pela qual cada crítico instruía seus leitores variava de acordo com suas concepções a respeito do tipo de música que seria mais adequado ao progresso da educação artística do povo. Nesse sentido percebemos uma vinculação estreita entre a crítica e um projeto civilizador, delineando os preceitos que deveriam ser seguidos para que o país, agora república, se civilizasse. O novo regime certamente ensejou, num primeiro momento, expectativas acerca da elevação e integração do país ao nível das civilizações europeias, que tinha como expressão máxima a capital francesa, modelo de desenvolvimento e modernidade a ser perseguido. Na perspectiva de que o Brasil encontrava-se na escalada inexorável do progresso, logo se percebeu que era preciso trabalhar para que a sociedade crescesse na mesma proporção. Para Oscar Guanabarino, afinado com os ideais republicanos da época, mais do que simplesmente fazer que uma obra se tornasse inteligível ao público, era preciso que este adquirisse refinamento no gosto, a fim de demonstrar "adiantamento".

\footnotetext{
O saber ouvir é uma arte; e este axioma colloca o publico sob a critica que neste momento, mais do que nunca, deve exercer as suas funcções com ardor, discutindo e insinuando, dirigindo e animando, para que a descrença não se apodere dos frequentadores dos espectaculos lyricos e vá reflectir sobre a população da nossa capital, dando direito a conclusões pouco honrosas para a nossa civilisação e estado de adiantamento de seu espirito para julgar obras do mais celebre compositor de musica dramatica que o nosso século tem produzido.

(GUANABARINO, O. Tannhäuser. "Artes e Artistas”. O Paiz, 03 out. 1892, p. 2.)
}

A relação entre a ópera e a cultura erudita que se deseja difundir datava de alguns séculos. O gênero surgiu nas cortes italianas e fora assimilada pela cultura burguesa, tornando-se em certa medida símbolo do luxo que, pertencente num primeiro 
momento aos círculos da nobreza, no século XVIII foi apropriada pela nova classe em ascensão, que procurava emular os padrões nobiliárquicos reconhecidos como símbolos de prestígio e poder (MAYER, 1987, p. 23-24). Foi assim que a ópera deixou o ambiente restrito dos salões das cortes e ganhou o espaço público dos teatros ou casas de ópera, centro da urbe burguesa (HOBSBAWM, 2013, p. 11). Não foi fortuita a decisão de Haussmann, ao projetar a nova Paris, em posicionar a Opéra Garnier em local privilegiado da cidade, modelo que seria copiado em várias outras cidades do mundo, inclusive no Rio de Janeiro de Pereira Passos. A ópera carregava, portanto, o status de arte de elite, expressão da cultura dominante, difundindo como tal valores e hábitos da classe social que a apropriara.

No Brasil, a ópera também era percebida como uma expressão artística da elite, conforme demonstrou Vanda Bellard Freire (FREIRE, 2013, p. 23). Durante o século $\mathrm{XIX},{ }^{3}$ vinculou-se intimamente à Corte, à presença da figura do imperador e da sua família no principal camarote do teatro, revestindo-se em um verdadeiro ritual, que "excedia o palco dos teatros" (Idem, p. 41). O nexo entre a ópera e a sociedade carioca se fortaleceu a partir da década de 1840, quando a cidade passou a receber companhias líricas e cantores de grande renome. Com a Proclamação da República e, logo em seguida, o processo de substituição em larga escala das elites, verificado por Sevcenko (SEVCENKO, 2003, p. 38), a ópera é apropriada pela burguesia, seguindo a tendência apontada por Arno Mayer. Essa interpretação coaduna com a análise de Jeffrey Needell, que ressalta que o teatro Lyrico oferecia ao público da nova elite em ascensão mais do que um espaço reconhecidamente aristocrático:

\footnotetext{
O Lírico oferecia, também, uma atração da qual as novas gerações, ou os novos-ricos, poderiam tomar parte sem que necessitassem de uma preparação tradicional. Como no caso das corridas de cavalos, a ópera exigia apenas uma participação passiva. Apesar de certa familiaridade com a arte torná-la mais palatável para aqueles que sufocavam numa gravata branca ou num corpete parisiense, todos concordavam que a ópera em si era secundária, comparada à ostentação evidente e à congregação da elite, que era, de fato, o centro dos acontecimentos. Parte da platéia, de acordo com o que se dizia na época, tinha apenas uma vaga idéia do que estava ouvindo. Mas todos, sem dúvida, tinham uma noção precisa do que estavam fazendo. (NEEDELL, 1993, p. 103)
}

Tal como colocado pelo historiador norte-americano, o teatro de ópera funcionava como um centro de convivência da elite endinheirada, a qual, mesmo que desprovida de uma educação que lhe proporcionasse uma compreensão mais profunda da música, reconhecia naquele local um espaço nobre, condizente com seu novo status. Certamente, para uma parte da plateia, o intuito em frequentar a ópera estava mais relacionado ao exibicionismo de sua posição social do que ao espetáculo em si. Mas tomar o todo pela parte, nesse caso, é um equívoco.

Como expressão da cultura dominante europeia, sendo apreciada na França, modelo principal de modernidade da época, a ópera deveria ser difundida entre a população, a fim de proporcionar o progresso cultural brasileiro, paralelo ao progresso político e econômico que então se vislumbrava para a República. As fontes que 
consultamos apontam para a necessidade dessa difusão, contrapondo-se à ideia do exclusivismo do ambiente operístico à elite republicana. A ideia de se disseminar a ópera estava sintonizada com o projeto civilizador, de mudanças dos costumes, que tentava então se implantar. Enquadrava-se, ademais, em um dos quatro princípios fundamentais apontados por Sevcenko, que guiaram a instalação do novo regime: "a negação de todo e qualquer elemento de cultura popular que pudesse macular a imagem civilizada da sociedade dominante" (SEVCENKO, 2003, p. 43). O resultado desse processo no âmbito da música se daria com um estímulo ao afastamento entre a música erudita e a popular no Brasil (ANDRADE, 2013, p. 12), que não foi, no entanto, totalmente bem-sucedida, tampouco abraçada por todos os intelectuais relacionados ao universo musical daquele momento.

Pesquisas recentes têm destacado experiências realizadas por músicos da época, que procuraram em alguma medida aproximar a música popular da erudita. Leopoldo Miguez e Alberto Nepomuceno, tomando como modelo a ópera de Wagner, procuraram desenvolver uma música erudita nacional a partir de elementos do folclore, algo que seria retomado anos mais tarde pela geração modernista. Houve ainda iniciativas mais ousadas, que incorporavam o batuque e o maxixe em composições (o próprio Nepomuceno experimentou essas misturas em algumas composições). Todas essas nuances tornam mais complexa a análise dos discursos sobre a ópera e sua relação com um projeto civilizador. As interpenetrações e influências mútuas entre cultura dominante e subalterna, bem como os conflitos delas resultantes, estão presentes nos periódicos consultados.

Observamos em diversas colunas jornalísticas duras críticas à cultura popular urbana, sobretudo em virtude de sua relação com a cultura africana, cuja sensualidade era imediatamente comparada à vulgaridade e à degradação moral (Cf. MACHADO, 2010, p. 117-160). A crítica, como porta-voz da cultura dominante letrada, buscava desqualificar as expressões culturais que viessem a destoar dos preceitos de civilidade que adotavam como horizonte. A crise dos teatros, tema debatido por vários intelectuais relacionados à temática artística nos jornais e revistas cariocas da época, seria, de acordo com a interpretação de vários deles, nada mais do que uma consequência da invasão de espetáculos de gosto duvidoso, descritos como pornográficos e moralmente reprováveis, que tomavam espaço do teatro dramático, da ópera lírica e dos concertos sinfônicos. Denúncias desse tipo saíam da pena de figuras relevantes da imprensa, tais como Oscar Guanabarino e João do Rio (FERREIRA, 2017, p. 400).

Por vezes, a reclamação recaía mesmo sobre gêneros ditos ligeiros, de música mais leve e aprazível ao grande público. Guanabarino deixou registrada sua insatisfação ao constatar que a opereta era mais apreciada que a ópera lírica: "Ainda ha reluctancia, força é confessal-o, mas quem ignora a existencia de um grande numero de pessoas que preferem a opereta ás operas lyricas?" (GUANABARINO, O. Lohengrin. Theatro Lyrico. "Artes e Artistas". O Paiz, 09 ago. 1894, p. 2). A invasão da opereta tornou-se mais saliente com o passar dos anos. Em 1903, um cronista que escrevia sobre a apresentação de um espetáculo desse gênero atestava o favoritismo pela opereta em detrimento da ópera, sintoma que estava inscrito no contexto da crise teatral 
(FERREIRA, 2017, p. 400).

Diante de aferições desse tipo, os críticos imbuídos de uma missão civilizatória buscavam convencer o grande público a comparecer a récitas de ópera: "Finalmente, caros patrícios, é de mister que nos convençamos de que uma opera bem cantada e por bons artistas é sempre um poucochinho melhor que o Solar dos Barrigas", diria o crítico Assis Pacheco (PACHECO, A. Tannhäuser. Theatro Lyrico. "Foyer". Diário de Notícias, 24 ago. 1894, p. 2). A predileção por gêneros ditos menores não se restringia ao ambiente dos teatros. Também em casas e salões particulares, a predominância de músicas de gêneros ligeiros era verificada a partir da procura, em editoras e casas musicais, por partituras de valsas, polcas, tangos, lundus, partes de operetas etc. A maior comercialização desse tipo de música levava, na visão de muitos intelectuais da época, a um círculo vicioso, fazendo diminuir o interesse, sobretudo das editoras nacionais, pela reprodução e disponibilização no mercado de partituras completas de óperas brasileiras (FERREIRA, 2017, 401). O interesse do público por outros estilos musicais afetava diretamente músicos e compositores brasileiros, que não viam possibilidade em conseguir seu sustento dependendo apenas da produção e execução de "música séria". Luiz de Castro alertou para esse problema em sua coluna, expressando sua preocupação com o campo de atuação limitado e pouco louvável dos raros músicos que se dedicavam a essa atividade profissional:

\footnotetext{
Porque, a verdade é esta: os nossos musicos e compositores são obrigados a dar lições e a ensinar o $a b c$ musical, se querem ganhar o pão nosso de cada dia, ou então tem de compôr polkas, tangos e valsas, para o que não faltam editores, porque, infelizmente, é esse genero de composições que entre nós tem mais sahida. (CASTRO, L. "Artes e manhas". Gazeta de Noticias, 28 mar. 1896, p. 2).
}

A crise dos teatros abrigava a "crise da ópera", mas não estava restrita a ela. Arthur Azevedo em inúmeras ocasiões buscou suscitar na imprensa um debate acerca da tal crise, no intuito de vislumbrar possíveis soluções para o problema. Sua maior preocupação relacionava-se ao teatro dramático, mas não deixava de abordar outros gêneros que considerava "elevados" e de que era admirador. ${ }^{4}$ Sua arma contra a decadência do gosto artístico brasileiro não se restringia à pena. Em 1895, convidou um grupo de intelectuais para fundar a Sociedade Theatro Brazileiro, com o intuito de fazer frente ao "estado decadente do theatro fluminense". A ideia era, "por meio de contribuições e subscripções, construir um theatro e manter uma escola de declamação" (Sociedade Theatro Brazileiro. "Artes e Artistas”. O Paiz, 27 mar. 1895, p. 3) Anos mais tarde, o dramaturgo considerava que a construção do Municipal poderia significar a "regeneração artistica" brasileira, se esse novo espaço fosse dedicado ao teatro dramático (AZEVEDO, A. Sobre theatro. O Paiz, 26 out. 1904, p. 1).

Em artigo publicado em 1906, no Almanaque d'O Theatro, Azevedo expunha, em números, a agonia do teatro no Rio de Janeiro, constatando que mesmo as companhias estrangeiras - categoria em que se classificavam as companhias líricas - já não encontravam na cidade a mesma quantidade de amadores de épocas anteriores. Afirmava ele que "[há] quinze annos passados, a media annual dos espectaculos no 
Rio de Janeiro era de 2.000; o anno passado realizaram-se apenas 1374 , entrando nesse numero 416 no Casino Nacional e 436 na Maison Moderne, que não são theatros propriamente ditos" (AZEVEDO, 1906, p. 8).

Oscar Guanabarino concordava com seu colega em relação à decadência artística do povo brasileiro. Além da constatação da aludida crise, investigou suas causas e sugeriu soluções que se conformassem ao diagnóstico feito por ele. Para o crítico, a decadência do teatro se inseria no escopo da decadência de outras formas artísticas, inclusive a música: "[o] theatro, como a litteratura, a musica e sobretudo a politica, resente-se das mesmas causas - a depravação do gosto, dos usos e dos costumes, e em alguns casos essa depravação já atingiu o grao de corrupção" (GUANABARINO, O. O theatro. Artes e Artistas. O Paiz, 24 fev. 1896, p. 3). Guanabarino, assim como outros intelectuais, estabelecia uma relação direta entre a arte e a moral, arte compreendida aqui como a expressão do belo no âmbito de uma cultura acadêmica, letrada e europeia. Como antípoda desses valores, a cultura popular era percebida como depravação tanto artística quanto moral. Era uma invasora do espaço sagrado do templo da arte, o teatro, assim como de outros recintos em que a arte "superior" deveria ter proeminência. O crítico afirmava que esse fenômeno vinha já de alguns anos:

E o povo sem theatro lyrico e ouvindo uma musica impossivel nas igrejas, inclusive na capela imperial, pendeu para a musica rythmica; veiu a polka e cruzou-se com as habaneras importadas do Rio da Prata pelas bandas do exercito, que voltaram triumphantes dos campos do Paraguay. Desse consorcio, n'um meio depravado e quasi corrupto nascem o maxixe, que póde e deve ser classificado como musica lasciva, sensual, e essa denominação é importante para o caso.

O maxixe das ruas, das serenatas, foi levado aos salões das sociedades carnavalescas e tornou-se tão popular que foi introduzido nos theatros pelos fabricantes de revistas.

O theatro foi o ponto de irradiação e por isso tudo tudo foi invadido, sendo certo que nos saraus familiares, nos salões mais serios da sociedade fluminense o maxixe já é a musica que substituiu o rythmo da polka, assim como já se tem dansado por gracejo essa dansa em casas de familia, deixando prever que ha de se generalisar.

A invasão do maxixe é manifesta e se ainda não chegou ao templo catholico, ao menos já o vimos nos concertos organizados pelos professores do Instituto Nacional de Musica [...].

Por ahi se vê que os factos se ligam e que a decadencia do theatro não póde ser estudada isoladamente, nem tão pouco devemos encaral-a fora da causa primaria, da depravação, de que é consequencia. (GUANABARINO, O. O theatro. "Artes e Artistas". O Paiz, 24 fev. 1896, p. 3)

O maxixe, ritmo que começava a se imiscuir na música erudita naquele momento, para horror de Guanabarino, era compreendido pelo crítico como uma mistura de culturas exteriores ao país, não podendo ser considerada, assim, como música brasileira: "Nesse amalgama descobrem-se traços dos rythmos africanos e o bambolear da musica hespanhola importada do Rio da Prata pelo exercito que voltou do Paraguay" (GUANABARINO, O. A musica II. Evolução artistica. “Artes e Artistas”. O Paiz, 05 maio 1900, p. 1). O autor deixava entrever, por esse trecho, a percepção, baseada em teorias científicas bastante difundidas na época (Cf. SCHWARCZ, 1993), de que a mescla cultural, decorrente da "mestiçagem racial" característica da população brasileira, 
consistia em um aspecto negativo, ressaltado pelos intelectuais. Ou seja, confluências, principalmente aquelas provenientes de bases consideradas como "degeneradas", adjetivo que era atribuído à cultura de origem africana, deviam se afastar do ideal de uma cultura nacional.

De fato, mesmo a reforma urbana empreendida no governo Rodrigues Alves (1902-1906), a qual pode ser compreendida como a materialização do modelo de modernidade há muito pretendido, possuía um componente fundamental nessa conjuntura. Sob o pretexto de deixar no passado as raízes coloniais do país, buscavase, sobretudo, esconder as classes populares e suas formas culturais. Baseado em três frentes (a reforma urbana, a cargo do prefeito Pereira Passos, a reforma do porto carioca, sob coordenação de Lauro Müller, e a higienização dos pontos insalubres da cidade, realizada por Oswaldo Cruz), aspectos que identificamos na discussão acima, acerca da cultura popular, eram invocados a guisa de pretexto para a modernização da cidade. O discurso oficial apontava para a necessidade em se modernizar o porto, em um primeiro plano, promovendo a ligação do Brasil com o exterior, por meio do comércio e visando à atração de imigrantes - e por isso a preocupação com os olhares dos estrangeiros que vinham à cidade (AZEVEDO, 2003, p. 42). A remodelação da cidade, com o alargamento das ruas e a construção dos bulevares, possuía uma relação direta com o que se pretendia para o porto. Era necessário não somente fazer chegar as mercadorias ao cais, mas escoá-las de maneira rápida e segura.

A consequência dessas medidas, no plano do engenheiro e prefeito da cidade, afetava as referências negativas à cultura popular que percebemos nos textos dos críticos. Ao tomar como modelo as reformas promovidas por Haussmann em Paris décadas antes, os ideólogos do novo espaço urbano carioca deixavam subjacente a necessidade visada em Paris em se manter a população sob controle, neutralizando espaços que poderiam ser empregados para barricadas (JORDAN, 1992, p. 99). O conceito de haussmanização, lembra David Jordan, foi adotado para definir reformas urbanas que se davam por meio da demolição (Idem, p. 102). Mais do que isso, envolvia um modelo mais amplo, em que estão subentendidas outras questões. Como ressalta Sandra Pesavento,

[...] se Paris se constitui no paradigma da cidade moderna, metonímia da modernidade urbana, isso se deve, em grande parte, à força das representações construídas sobre a cidade, seja sob a forma de uma vasta produção literária, seja pela projeção urbanística dos seus projetos, personificados no que se chamaria o "haussmanismo". (PESAVENTO, 1999, p. 31)

O modelo consistia, pois, em uma representação que abrangia diferentes aspectos do que se visava retratar do real. Dentre eles, a segregação de uma classe popular que deveria ser expulsa do centro da cidade, com seus costumes e valores considerados pouco civilizados - senão bárbaros -, deixando à vista dos estrangeiros e da alta classe somente aquele cenário construído para o desfile de casacas e vestidos, em ruas largas e arejadas, tal como era constituído no imaginário o ideal de uma metrópole que se pretendia moderna. 
No âmbito dos hábitos culturais, à população que se colocava em posição intermediária e não era expulsa dos cortiços que seriam colocados abaixo pela política demolidora de Pereira Passos, era necessário oferecer opções de entretenimento cultural que lhe permitisse o afastamento da cultura popular que se procurava banir do Rio de Janeiro remodelado. A ideia de cultura que emergia das fontes referia-se, assim, à formação do gosto artístico, que afastava os iniciados da selvageria. Uma vez que se relacionava o perecimento do teatro à resistência ao progresso, a crise teatral era apontada como consequência da ignorância - ou falta de cultura - do povo que habitava a capital, de forma que a educação seria o remédio que sanaria o problema. Todos esses aspectos aparecem concatenados em coluna não assinada no jornal $O$ Paiz de 22 de março de 1901, que tratava do Theatro Municipal:

\footnotetext{
Esse facto da decadencia da scena brazileira - como o da imprensa, que ainda hontem dois dos nossos collegas accusavam - como o da repugnancia a medidas elementares de hygiene, entre as quaes estão a vaccinação e a revaccinação - como o da imcomprehensão do registro civil e do recenseamento - como o da abundancia dos crimes de sangue - tudo isso são symptomas de um unico mal: a ignorancia popular, a falta de escolas primarias.
}

Argumentos semelhantes eram usados por vários outros colunistas e escritores. Não raro, as críticas recaíam ainda sobre os empresários teatrais, por atenderem com leniência às demandas do público, deixando de se ocupar de sua responsabilidade em trazer espetáculos de qualidade para educar o público, preferindo os lucros ao papel instrutivo. Carlos Parlagreco tratou em um artigo sobre o "mercantilismo dos emprezarios e dos musicos que exploram os publicos, fazendo-lhes as vontades; pragas estas que ainda são vivas nos maiores centros artisticos do mundo" (PARLAGRECO, C. Concerto Historico. “Artes e Artistas”. O Paiz, 21 jul. 1896, p. 2). Um cronista do Diário de Notícias, em 16 de outubro de 1892, asseverava, por outro lado, que "as emprezas theatraes não vêm abrir escolas para fazer a educação musical das platéas, repetindo boas operas com casas vasias. Se o Trovador render mais do que o Tannhäuser, ellas preferirão a velha partitura do Verdi ao grande trabalho de Vagner [sic]". Guanabarino, por sua vez, ponderava que as empresas não podiam deixar de considerar o gosto do público. ${ }^{5}$ Ademais, afirmava ele que "custa muito caro educar o povo no terreno musical, impondo-lhe partituras que elle ainda não está preparado para comprehender e apreciar" (GUANABARINO, O. "Primeiras representações". O Paiz, 30 de abril de 1906, p. 2).

Os aspectos cotidianos de sobrevivência de artistas e empresários, em várias ocasiões, eram apresentados nos textos de críticos e cronistas como empecilhos para a difusão da "boa música". O preço cobrado para se frequentar espetáculos como a ópera podia ser outra explicação para o afastamento de gêneros considerados superiores. A ópera, em particular, dependia quase exclusivamente de companhias estrangeiras, uma vez que a cidade não apresentava condições de possuir uma companhia lírica própria - do que se ressentiam alguns críticos e cronistas. Essas empresas estavam, portanto, sujeitas a flutuações de câmbio e ao mercado de cantores estrangeiros, conforme testemunha um cronista: "A baixa do cambio tornou impossivel o contrato 
de figuras de primeira ordem. Era preferivel que não tivessemos opera nenhuma desde que não podiamos tel-a excellente" (PANGLOSS. O Dia. O Paiz, 02 mar. 1905, p. 2). Por isso, a lógica de mercado a que elas se sujeitavam acabava por favorecer a um "círculo vicioso", o que ia de encontro ao ideal almejado pelos críticos, como deixa claro um cronista anônimo:

\begin{abstract}
O publico affastado da opera, pelo preço exorbitante das ultimas temporadas, foi-se amoldando á musica explorada nos theatros onde imperam as magicas e revistas, e se não fossem os concertos populares e o lyrico da empreza [Sansone] o gosto artistico desse mesmo publico correria o risco de perverter de todo. (Fausto. "Artes e Artistas". O Paiz, 12 nov. 1896, p. 3)
\end{abstract}

Nesse sentido, as companhias líricas populares, ao levar espetáculos líricos a um público mais numeroso, cobrando valores de entrada mais modestos, consistiam em instrumentos para o desenvolvimento e aperfeiçoamento do gosto artístico de espectadores desprovidos dos altos recursos demandados para se frequentar o Theatro Lyrico ou o Municipal, teatros considerados de primeira ordem e mais elitizados (FERREIRA, 2017, p. 286). Tais companhias, nesse sentido, realizavam um "serviço" à educação artística do povo e ao gosto musical: "O desenvolvimento das artes, dependendo da educação do povo, principalmente em se tratando da arte musical, não póde ser realizado por outro processo tão attrahente como este"; eram consideradas como companhias de "vulgarisação de operas de propaganda e de educação musical” (Companhia Lyrica Sansone. "Theatros e Diversões”. O Tempo, 08 nov. 1893, p. 2). Além disso, as companhias líricas de segunda ordem traziam um repertório "que a grande parte da população, a maioria, sem duvida, não conhece", ainda que algumas óperas se encontrassem "ha muito tempo no dominio da musica popular" (Companhia lyrica. Apollo. “Artes e Artistas”. O Paiz, 27 out. 1902, p. 2).

Os intelectuais, ao manifestar sua preocupação, destacavam a premência pela educação artística do povo, para que a situação pudesse ser revertida. Arthur Azevedo concordava com colegas que apontavam a carência de uma educação musical no Brasil. A propósito da ópera Saldunes, de Leopoldo Miguez, o dramaturgo, assinando o texto com um de seus pseudônimos - "Eloy, o heróe" -, mencionou a desorientação do público, que encontrou dificuldades para compreender a música escrita pelo compositor brasileiro (AZEVEDO, A. A Semana. O Paiz, 23 set. 1901, p. 2). Focava-se a questão da música - e da arte - como algo a ser racionalizado, a ser apreendido pelo conhecimento científico. Sendo o público despreparado, ele dependia de várias audições para compreender obras mais complexas (Companhia lyrica. Apollo. Artes e Artistas. O Paiz, 27 out. 1902, p. 2). Julia Lopes de Almeida percebeu, em relação à mesma ópera de Miguez, aquilo que Azevedo havia exposto. Porém, diferente do colega, ela asseverava que a música, para o público, era tão somente a emoção, e que não deveria ser diferente.

A maioria do publico que vai ao theatro ouvir uma opera, não trata, por incompetente, de averiguar se ella é feita desta ou daquella maneira, se a sua instrumentação obedece a todos os primores de uma orchestração opulenta, se a sua tessitura é perfeita, e as suas 


\begin{abstract}
harmonias bem combinadas.
O que elle vai buscar lá é a emoção, o sentimento que transbordará e evocar-se-há da musica com a espontaneidade perturbadora com que o perfume sae de uma flor!

Parece-me que a arte, a não ser para os artistas, não é coisa que se entenda, mas que se sinta. Que importa á maioria que os processos por que tal partitura é feita, sejam complicados e ella dolorosamente trabalhada, se do seu conjunto espinhento e bravio não voou nem uma phrase que lhe fizesse vibrar os nervos impassiveis?

Em verdade é muito frequente ouvir-se dizer: eu não gostei desta ou daquella opera porque não a entendi.

Essa modesta confissão de incompetencia, que, aliás, só é feita em relação á musica, visto que para as outras artes toda a gente se julga habilitada e com direito a uma critica definitiva, deve, até certo ponto, consolar os maestros. (ALMEIDA, J. L. Harmonias. O Paiz, 06 out. 1901, p. 1)
\end{abstract}

É importante destacar que a percepção dos críticos quanto ao público carioca era ambígua e contraditória. Dessa forma, alguns cronistas e colunistas pareciam amenizar a decadência do teatro verificada pela crítica especializada e, até mesmo, distorcer a imagem da cidade. Foi assim que Julia Lopes de Almeida retratou em um texto o Rio de Janeiro como capital artística da América do Sul, título que se atestava, segundo ela, pela quantidade de artistas existentes na cidade (ALMEIDA, J. L. Projectos de Arte. O Paiz, 12 jul. 1903, p. 1). Certamente, a aferição de Almeida consistia em um exagero, que não coadunava com o que a crítica especializada daquela época observava e discutia. Também destoava das constatações frequentes de que as companhias líricas, ano após ano, arcavam com graves prejuízos na capital brasileira (FERREIRA, 2017, p. 227). Outro traço dessa contradição eram os textos que ora viam o público como o mais correto avaliador das qualidades de uma companhia lírica, ora como resistente a novidades, principalmente se essas novidades dependessem de maior atenção e concentração, como no caso da música sinfônica e das óperas de Wagner (Idem, p. 322). De maneira geral, a percepção de que faltavam ao público carioca elementos que favorecessem a compreensão de obras operísticas e sinfônicas acentuou-se com o passar dos anos. Nesse sentido, a crítica insistia em sugestões que viessem a propiciar a formação adequada do público, fosse por meio da educação formal, com a inclusão de conteúdos relativos à "ciência musical" na escola básica, fosse pela construção de teatros estatais que proporcionassem um entretenimento de alto nível à população a preços acessíveis. Em março de 1890, o jornal O Paiz publicou um abaixo assinado elaborado pelo ator Luís Candido Furtado Coelho para a "construcção do edificio e bases de manutenção dos theatros lyrico e dramatico do estado". Entre os argumentos destacados para a empreitada, o ator mencionava a compreensão de que o teatro em um país era "o thermometro, por assim dizer, da civilisação de seu povo" (O theatro nacional. Artes e Artistas. O Paiz, 22 mar. 1890, p. 2), ideia compartilhada por vários outros intelectuais da época, que viam na subvenção estatal republicana uma possível saída para o problema.

Tinha-se que "entre os meios de educação popular está o theatro" (Idem) e o teatro nacional consistia, por sua vez, em "reflexo da civilização dos povos" (COLLOR, L. O Theatro Nacional. Enquête. Opinião do Sr. Oscar Guanabarino. O Paiz, 20 abr. 1912, p. 3), devendo ele "educar e divertir" (Theatro Municipal. O Paiz, 18 mar. 1911, 
p. 1). Dessa forma, apontava-se a necessidade de o poder público aderir a essa causa, uma vez que, "[a] sociedade brazileira não tem caracteristico proprio, e os costumes do povo darão quando muito, vaudevilles e burletas, e da nossa historia, apenas poderemos obter dramalhões" (COLLOR, Op. Cit.). Com um teatro mantido pelo governo, alimentava-se ainda a esperança de que seria possível diminuir a dependência estrangeira na indústria teatral na cidade (GUANABARINO, O. Theatro Lyrico. Artes e Artistas. O Paiz, 12 ago. 1902, p. 2).

A visão otimista a respeito do público e do progresso artístico brasileiro foi abordada também por Olavo Bilac. O escritor, dedicando sua conhecida eloquência em discurso proferido na inauguração do Theatro Municipal, ressaltava o teatro como "educador e engrandecedor do espirito humano". Prosseguia seu discurso enfatizando que aquela ocasião consistia em uma festa que atestava a cultura e a civilização do povo brasileiro, que já cultuava a arte tal como uma religião e, por fim, tinha então o seu templo. "O monumento emblemático de nosso valor artístico", segundo Bilac, seria o local de sociabilidade, o "salão nobre da cidade, o seu forum social, a arena elegante em que se travam os torneios da moda, da graça, da conversação e da cortezia" (BILAC Apud. GUANABARINO, O. Theatro Municipal. A inauguração. O Paiz, 15 jul. 1909, p. 2). No ano seguinte, Luiz de Castro, que retornava à imprensa depois de afastado por alguns anos, verificava que o gosto musical no Rio de Janeiro vinha melhorando, ainda que lentamente: "Nestes quatorze annos nem só materialmente termos progredido. Tambem em gosto musical temos andado alguma coisa para frente, si bem que devagar" (CASTRO, L. Preludiando. Notas de Musica. A Noticia, 04 e 05 maio 1910, p. 2). Castro completava seu raciocínio apontando outros sintomas que reforçavam sua percepção, tais como a afluência aos concertos durante a exposição de 1908; os concertos promovidos pelo Instituto Nacional de Música; e a participação brasileira no Congresso de Música.

É importante destacar que a crise teatral observada na cidade por vários cronistas e críticos não era, ao que parece, uma exclusividade carioca ou brasileira. $O$ correspondente d'O Paiz na capital francesa relatou, em artigo de 1894, as dificuldades por que passava o teatro sério em Paris, cuja causa estaria, segundo ele, no "augmento de recintos de prazeres frivolos e baratos", os quais "fazem uma concorrencia diabolica aos verdadeiros theatros" (CARVALHO, X. "Carta parisiense". O Paiz, 25 maio 1894, p. 2). Completava ainda o autor que o custo para assistir a peças sérias era alto na cidade, e a carestia que a assolava impedia que grande parte da população frequentarsse bons teatros, passando a optar por divertimentos mais acessíveis aos bolsos. Assim, percebemos que a "avançada" e "civilizada" Paris passava por problemas muito parecidos aos verificados no Rio de Janeiro, de forma que podemos inferir que uma boa parte da imagem construída sobre a cidade-modelo não passava de uma idealização que pouco correspondia à realidade.

Assim, apesar de o modelo francês ser adotado como padrão de civilidade, certas modas provenientes daquele país nem sempre agradaram aos críticos musicais. $\mathrm{Na}$ virada da primeira década do século XIX, ressurgia um "genero meudo, ligeiro, secundario", que exprimia o espírito de otimismo que marcaria a belle époque. A 
opereta, "obra de divertimento, de alegria mesmo", da qual já tratamos rapidamente, reapareceu como uma onda que varreu os teatros brasileiros. As principais composições do gênero renovado eram provenientes da Áustria, tendo como principais compositores Johann Strauss e Franz Lehár, os quais mesclavam grandes valsas a temas leves. Era moda em Paris e virou uma verdadeira febre no Rio de Janeiro, com destaque para a Viúva Alegre, de Lehár (A resurreição da opereta. O Paiz, 17 dez. 1911, p. 8). A nova tendência, mesmo que atestada pelos requintados palcos franceses, foi rechaçada por aqueles que a viam como gênero inferior à ópera (CASTRO, L. Palestras musicaes. Artes e Artistas. O Paiz, 26 ago. 1911, p. 7). Oscar Lopes expressou sua aversão à invasão da opereta vienense na cidade, cantada até por crianças em uma escola pública. Para Lopes, "pareceu um attentado contra o pudor dessas mesmas crianças, um crime de leso-bom gosto, uma falta contra a nosso futuro e contra a nossa propria nacionalidade". As implicações futuras da difusão da opereta seriam, na opinião dele, catastróficas ao Brasil.

\footnotetext{
Que especie de gente somos nós, que assim nos menosprezamos, indo pedir emprestado á opereta ou á opera comica as canções para os nossos filhos pequeninos? Que será feito de nós, dentro de vinte annos, se ás mãis e aos homens desse tempo nós hoje ensinamos, certamente á guiza de educação civica, os trechos populares e lascivos de uma viuva alegre qualquer?

Esta terra é a Cafraria ou é um paiz que presume ter um logar na civilização? (LOPES, O. A Semana. O Paiz, 18 ago. 1912, p. 1)
}

As ameaças aos planos de civilização do Brasil pareciam vir de todos os lados. Por isso, os intelectuais que atuavam nos periódicos buscavam usar de sua posição, como formadores de opinião e influenciadores, para divulgar o que consideravam ser importante para a modernização do Brasil, de acordo com preceitos então concebidos acerca do que era moderno, civilizado, moral. Por meio da frequência a espetáculos líricos, consideravam que o público carioca poderia "evoluir" culturalmente, acompanhando o desenvolvimento que aceitavam como "natural", dentro de uma perspectiva positivista e linear da história. A ópera, como espetáculo e forma artística que abarcava valores que deveriam ser difundidos e introjetados na população da capital brasileira, era vista como possível veiculadora dos preceitos civilizatórios que então se desejava implantar.

\section{Considerações finais}

Os periódicos cariocas eram um canal de comunicação entre seus leitores e outros locais do país e do mundo. As novidades chegavam por meio da imprensa e uma parcela dessas novidades dizia respeito à ópera. $O$ espaço dedicado a este gênero artístico nos jornais nos permitiu vislumbrar o interesse dos leitores pelas notícias relacionadas ao mundo operístico. A ópera era considerada um espetáculo de bomgosto e civilizado; "verdadeira arte e boa musica" ("Syndicato Lyrico Fluminense". 
Jornal do Brazil, 06 jan. 1905, p. 1). Ao absorver hábitos e costumes reconhecidamente europeus, os cariocas podiam se comparar a outras grandes cidades do mundo, adquirindo o que então concebiam como civilização e cultura (ELIAS, 1994, p. 54), termos que estavam intimamente relacionados na tradição francesa, importada pelo Brasil. O processo de urbanização e modernização acelerado pela Proclamação da República reforçou a inevitabilidade da disseminação de "bons costumes", como esforço para civilizar a capital. Esse processo não se deu, contudo, de maneira fácil e nem instantânea. Como em pouco tempo perceberiam os intelectuais que formulavam suas teorias acerca do processo evolutivo do Brasil, a simples instauração de um novo sistema de governo não fez do país, nem de sua capital, e nem mesmo de sua elite, ícones de civilidade aos moldes europeus.

Nesse sentido, ao falar em uma "inserção compulsória do Brasil na belle époque", Nicolau Sevcenko sintetizou com brilhantismo o esforço empregado para enquadrar o país na marcha inexorável do progresso (SEVCENKO, 2003, p. 35). No âmbito de uma concepção positivista e evolutiva da história, pensava-se que instalada a república, o Brasil iria modernizar-se instantaneamente, o que, naturalmente, não ocorreu. Aspectos que deveriam ser suplantados, porque ligados ao "atraso" ou a processos históricos que se desejava esquecer, teimavam em se fazer presentes, frustrando a elite que idealizara o novo regime. Foi nesse contexto que intelectuais encetaram uma verdadeira campanha, no intuito de extirpar a feição colonial e ultrapassada que marcava o país, a começar por sua capital. Se as reformas urbanas ainda demorariam um pouco para se efetivarem, aquelas que visavam transformar os espíritos dos cidadãos podiam ser colocadas em prática desde os primeiros momentos do novo regime. Um primeiro passo se dava por meio da marginalização da cultura popular urbana, considerada degradante, em favor da cultura erudita europeia. Nesse contexto, tudo o que viesse a se relacionar com o popular, especialmente na música, era desvalorizado. Um cronista falava, então, da "falta de gosto que vem da nossa canção popular, da modinha desasizada, sem grammatica, sem nexo, sem espirito" (LOPES, O. "A Semana". O Paiz, 16 jul. 1911, p. 1). Traços de uma cultura considerada "degenerada" estavam disseminados por vários locais, da rua aos teatros, e, por isso, seria preciso persuadir o "povo" a adotar "bons costumes", adquirir "bom gosto", que levariam à elevação do Brasil, a começar pela sua capital. Os jornais, por meio de seus colunistas e críticos, foram os principais propagadores da campanha pela "boa música", buscando convencer seus leitores a abandonar hábitos inapropriados ao ideal civilizatório. Os críticos consistiam em formadores de opinião, difusores de conceitos de civilidade que deveriam ser espalhados e adotados pela sociedade.

Como elemento de cultura, pleno de significados, a ópera consistiu em representação que poderia contribuir na formação de uma identidade nacional, uma vez vinculada a um projeto civilizador. Ela consistia em veiculadora de códigos múltiplos, compartilhados e compreendidos coletivamente e, por isso, parte dos imaginários sociais que se conformavam ou se ressignificavam naquele momento, auxiliando na difusão de valores e dando sentido aos conceitos a ela relacionados, como modernidade, gosto, arte, progresso etc. 
Como representação e prática, a ópera compreendia um sistema de significações, socialmente e historicamente constituído, com capacidade de servir aos mais diversos propósitos. Confirmamos, por meio dela, a ideia da ambiguidade verificada em relação ao período. Pretendia-se uma modernização de fachada, que visava mais à aparência do que à transformação das estruturas em que se estabelecia a conformação social. Nesse sentido, a reforma urbana promovida na capital da república materializou em todos os sentidos a ideia de modernidade que estava em vias de se implantar. É importante destacar, nesse sentido, que os planos de levar a ópera para a população excluía de seu campo os operários, os ex-escravos, os empregados domésticos, ou seja, aqueles que se encontravam à margem do mundo do trabalho e da sociedade de maneira geral. Como representação da modernidade, a ópera compreendia os valores europeus, letrados, cultos, ou seja, plenos do que se considerava como erudição e cultura, visando suplantar a cultura popular urbana, que trazia em seu âmago a cultura das ruas, dos negros, sua sensualidade e sua afronta aos padrões morais que a elite tentava impor.

A ópera tem suas nuances envoltas em um campo de disputas e conflitos. Expressão da cultura europeia, elitista, letrada, ela foi adotada como arma de combate contra as manifestações da cultura popular urbana, em que era acentuada a presença da mestiçagem, dos batuques, da sensualidade, que exprimia o passado escravocrata, a música primitiva e rítmica e a ausência de moral, respectivamente. Mesmo assim, ainda que vinculada a uma cultura dominante, não possuía de forma alguma seu espaço na sociedade assegurado. Era preciso convencer leitores sobre a sua importância. Era preciso levar mais público aos teatros para que adquirissem um "gosto refinado". Era preciso impulsionar a modernização de um país que estava fadado, de acordo com as teorias científicas da época, ao fracasso ou, no mínimo, à tutela cultural da Civilização (com letra maiúscula, conforme se referiam à Europa os intelectuais da época). Era parte, portanto, de um projeto político amplo do que então se convencionou como "moderno", suplantando um passado que se pretendia esquecer ou apagar.

\section{Referências}

ANDRADE, C. L. B. A Gazeta Musical: positivismo e missão civilizadora nos primeiros anos da República no Brasil. São Paulo: UNESP, 2013.

AZEVEDO, A. N. A reforma Pereira Passos: uma tentativa de integração urbana. 
Revista Rio de Janeiro, Rio de Janeiro, n. 10, p. 39-79, mai./ago. 2003.

BACZKO, B. Imaginação social. In.: Enciclopedia Einaudi. V. 5. Lisboa: Imprensa Nacional-Casa da Moeda, 1985.

BAKHTIN, M. A cultura popular na ldade Média e no Renascimento: o contexto de François Rabelais. 4. ed. São Paulo: Hucitec / Brasília: Editora Universidade de Brasília, 1999.

BARRETO, L. Recordações do escrivão Isaías Caminha.10. ed. São Paulo: Ática, 2002.

BOURDIEU, P. A distinção: crítica social do julgamento. São Paulo: Edusp; Porto Alegre: Zouk, 2007.

BUDAZS, R. Do libreto ao cordel. Pesquisa na Biblioteca Nacional. Rio de Janeiro: Fundação Biblioteca Nacional, 2010, p. 117-129.

CARVALHO, J. M. A formação das almas: o imaginário da República no Brasil. São Paulo: Companhia das Letras, 1990.

CHARTIER, R. O mundo como representação. Estudos Avançados. São Paulo, v. 5, n. 11, 1991, p. 173-191.

2002.

. A história cultural: entre práticas e representações. 2. ed. Lisboa: Difel,

DE LUCA, T. R. História dos, nos e por meio dos periódicos. In: PINSKY, C. B. (orgs.). Fontes Históricas. São Paulo: Contexto, 2005, p. 111-153.

ELIAS, N. O processo civilizador. Vol. 1. Rio de Janeiro: Jorge Zahar, 1994.

FERREIRA, L. C. S. Cenários da ópera na imprensa carioca: cultura, processo civilizador e sociedade na belle époque (1889-1914). Brasília: 2017. 692 f. Tese (Doutorado em História - Programa de Pós-Graduação em História, Universidade de Brasília).

FREIRE, V. B. Rio de Janeiro, século XIX: cidade da ópera. Rio de Janeiro, Garamond: 2013.

GINZBURG, C. O queijo e os vermes: o cotidiano e as ideias de um moleiro perseguido pela Inquisição. São Paulo: Companhia das Letras, 1998.

HALL, S. Cultura e representação. Rio de Janeiro: PUC-Rio, 2016.

2002.

. A identidade cultural na pós-modernidade. 7. Ed. Rio de Janeiro: DP\&A,

HELIODORA, B.; DEL RIOS, J.; MAGALDI, S. A função da crítica. São Paulo: Giostri, 2014.

HOBSBAWM, E. Tempos fraturados: cultura e sociedade no século XX. São Paulo: Companhia das Letras, 2013.

JORDAN, D. P. Baron Haussmann and Modern Paris. The American Scholar. v. 61, n. 
1, Washington DC, p. 99-106, 1992.

MACHADO, C. Batuque: mediadores culturais do final do século XIX. In.: MORAES, J. G.; SALIBA, E. T. (orgs.). História e música no Brasil. São Paulo: Alameda, 2010, p. 117-160.

MAYER, A. J. A força da tradição: a persistência do Antigo Regime (1848-1914). São Paulo: Companhia das Letras, 1987.

MONTEIRO, M. A construção do gosto: música e sociedade na Corte do Rio de Janeiro - 1808 - 1821. Cotia/SP: Ateliê Editorial, 2008. . Aspectos da música no Brasil na primeira metade do século XIX. In.: MORAES, J. G.; SALIBA, E. T. (orgs.). História e música no Brasil. São Paulo: Alameda, 2010, p. 79-118.

NEEDELL, J. D. Belle époque tropical: sociedade e cultura de elite no Rio de Janeiro na virada do século. Rio de Janeiro: Companhia das Letras, 1993.

PEREIRA, A. R. Entre a crítica e o deboche: a "música nacional" nas pautas da imprensa no Rio de Janeiro oitocentista (1882-1899). In.: ENGEL, M. G.; SOUZA, F. F.; GUERELLUS, N. S. (orgs.). Os intelectuais e a imprensa. Rio de Janeiro: Mauad X, Faperj, 2015, p. 101-129. . Música, sociedade e política: Alberto Nepomuceno e a República Musical. Rio de Janeiro: Editora UFRJ, 2007.

PESAVENTO, S. J. História \& História Cultural. Belo Horizonte: Autêntica, 2003. . O imaginário da cidade: visões literárias do urbano - Paris, Rio de Janeiro, Porto Alegre. Porto Alegre: UFRGS, 1999.

SCHWARCZ, L. M. (coord.). A abertura para o mundo: 1889-1930. História do Brasil Nação: 1808-2010. V. 3. Rio de Janeiro: Objetiva, 2012.

SEVCENKO, N. Literatura como missão: tensões sociais e criação cultural na Primeira República. 2. Ed. São Paulo: Companhia das Letras, 2003.

SODRÉ, N. W. História da imprensa no Brasil. 4. ed. Rio de Janeiro: Mauad, 1999. WILLIAMS, R. Cultura. São Paulo: Paz e Terra, 2011. 


\section{Notas}

10 Jornal do Commercio, que teve seu lançamento ainda na década de 20 do século XIX, consistia em um dos maiores jornais, com relevante tradição no Rio de Janeiro na virada do século. Ainda existente, é um dos jornais mais antigos em circulação no Brasil.

2 Referimo-nos a uma passagem em que Isaías Caminha, narrador da história, fala sobre a pressa em dar notícia a respeito de um provável assassinato, do qual se sabia muito pouco. Enquanto os repórteres se dirigiam para o local do crime, era preciso já dar início à "cabeça” da reportagem, com floreios e especulações, no intuito de ser o primeiro jornal a dar a notícia.

3 É provável que esse tipo de espetáculo já fosse conhecido ainda nos tempos coloniais, mas fora com a vinda de D. João VI que ela se tornou um hábito no Rio de Janeiro.

4 Como dramaturgo, Azevedo costumava ser mais enfático em relação à necessidade de se apoiar a arte dramática nacional, que vivia, segundo ele, situação mais precária do que a ópera. Mas não deixava de revelar certa preocupação com o teatro lírico, conforme percebemos em várias de suas colunas. 5 Guanabarino parecia assumir, em alguns momentos, uma postura ponderada acerca da educação musical do público, deixando entrever que ela deveria se dar de maneira gradual, divergindo nesse ponto com os intelectuais atuantes no Instituto Nacional de Música, que pareciam querer impor, em certos momentos, uma estética musical para a qual o público ainda se encontrava despreparado e pouco receptivo. Vale destacar que, por esse motivo, o crítico de O Paiz, ao contrário de outros colegas da imprensa, defendia o uso da ópera italiana como forma de educar o povo, em vez de buscar essa educação por meio dos concertos sinfônicos e óperas wagnerianas, como pregava, por exemplo, Luiz de Castro.

Liliane Carneiro dos Santos FERREIRA. Doutora e Mestre em História pela UnB, Licenciada e Bacharel em História pela Universidade Federal de Santa Catarina (2002). Atualmente é Analista em Ciência e Tecnologia da Coordenação de Aperfeiçoamento de Pessoal de Nível Superior, lotada no Arquivo Central, desempenhando atividades de pesquisa sobre a história da Capes, organização e curadoria de exposições e elaboração de projeto de memória institucional. 